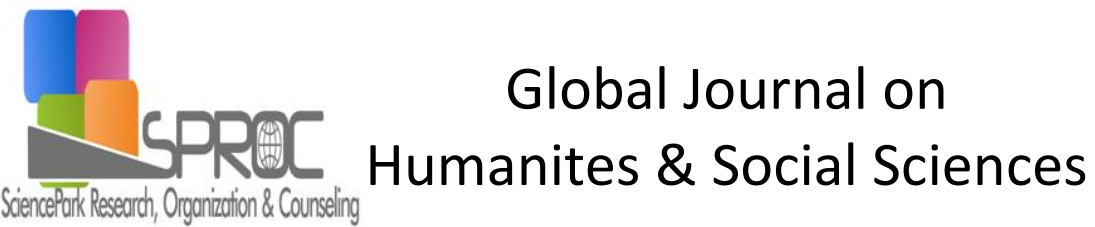

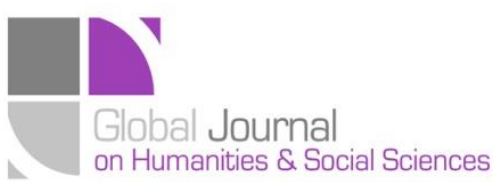

Vol 3 (2016) 135-142

Selected Paper of 4th World Conference on Design and Arts, (DAE-2015)

26-28 June 2015, St.Petersburg Christan University, St. Petersburg, Russia.

\section{Influence of Turkish coffee culture on the design of small home appliances: Turkish coffee makers}

Ebru Gedik*, Faculty of Architecture, Department of Industrial Design, Gazi University, Ankara, 06000, Turkey.

S.Serpil Erdonmez, Faculty of Engineering, Department of Manufacturing Engineering, Atılım University, Ankara, 06000, Turkey.

N.Sule Atılgan, Faculty of Architecture, Department of Industrial Design, Gazi University, Ankara, 06000, Turkey.

\section{Suggested Citation:}

Gedik, E., Erdonmez, S.,S. \& Atılgan, N., S. (2016). Influence of Turkish coffee culture on the design of small home appliances: Turkish coffee makers,

[Online]. 03, pp 135-

142. Available from: http://sproc.org/ojs/index.php/pntsbs

Received January 10, 2015; revised March 04, 2015; accepted May 10, 2015.

Selection and peer review under responsibility of Prof. Dr. Milan Matijevic.

C2015 SciencePark Research, Organization \& Counseling. All rights reserved.

\begin{abstract}
Culture is a complex integration consisting of material and moral stuffs by living people as a member of society who are learned by doing and taught. Therefore, it includes and effects lots of areas such as languages, beliefs, moral laws, consumption habits to hold together people in society. Culture also has over power on design and design processes like the other areas. These influences are inevitable because culture and design are in an interaction that enrich and nourish each other. Product design is one of the design area and one of the influential areas for individuals to show their culturel back grounds in a concrete way. That's way, product design is an important line to put down the facts of the notion of culturel effects.

The aim of this study is to examine the influences of Turkısh Coffee culture which has an important place in Turkish culture and has own rituels, Turkish has the effects of small house hold appliances aims to examine the culture of design on the Turkish coffee machines. To see what these effects are within the scope, firstly, Turkish coffee culture should be examined, after then with the examination of mechanization process of the Turkish coffee, Turkish coffee culture has tried to explain the traces in this design.
\end{abstract}

Keywords: culture, design, product design, turkish coffee cultur, turkish coffee maker.

* ADDRESS FOR CORRESPONDENCE: Ebru Gedik, Faculty of Architecture, Department of Industrial Design, Gazi University, Ankara, 06000, Turkey. : ebrugedik@hotmail.com.tr / Tel.: +90-505-375-2200 


\section{Introduction}

Culture is cumulative civilization of a society or of all societies; it is a combination consisting of everything that human being learns by experience and practicing as a member of society. Turkish Language Association (TDK) defines the culture as "all kinds of tools used to get essential needs such as food, clothing, accommodation, shelter; techniques applied; opinions, abilities, beliefs, traditional, religious, social, political orders and authorities; views, senses, attitude, behaviour and way of life: all products created by the public or a society in material and spiritual environment". As it is understood, culture covers and has influences on many areas such as language, belief, custom, law, production and consumption patterns that provide unity for the individuals of a society.

Mentality, attitudes, point of views and behaviours of an individual are shaped according to the culture in which they live and therefore they have cultural acquisitions. A cultural acquisition constitutes the basis for acculturation. Individuals in acculturation process reviews the acquisitions belonging to their own culture according to their own behaviour pattern, perspective and views (Balaman, 1981). Reinterpretation of the concept of the culture within the context of social life is important in terms of taking its place for today's requirements and transferring them to the next years. The main field where the culture is reinterpreted is design. Basic definition of design is an opinion and an action. This action is transformed to product design through creativeness (Onal, 2011). Culture has deeply influences the design and design related processes. This impact is inevitable because there have been an interaction between the areas of culture and design that supports and nourishes each other. Product design is one of the areas in which the individuals reflect their observations, knowledge, achievements in daily life and cultural backgrounds. Therefore product design is an important field which must be searched through in order to put forward the effects of the concept of culture.

Coffee consumption and culture has a long history in our country. This culture, which still exists today from the Ottoman Empire has become a part of our daily lives and created its own rituals, habits and the products in time. This study aims to present the impacts of Turkish coffee culture on design which has an important place in Turkish culture. Recently, small household appliances are mostly affected by this impact. The latest products of the Turkish coffee culture are Turkish coffee machines. In this article history, culture and the products of the Turkish coffee have been investigated through the literature and then culture- design relation has been presented by analysing sample products from mechanization process in this regard.

\section{History of Turkish Coffee}

Despite the fact that when coffee was started to use as a drink first is unknown, all records say that it has spread all over Islam world in the XVI ${ }^{\text {th }}$ century. According to the epistle of the Abdulkadir elCeziri,

first news about the popularity of coffee in Yemen as a drink spread to Kairo in the beginning of this century (Hattox, 1998). There has been a rumour not widely known is that the first person who roasted and used coffee as a drink is Prophet Suleiman. Again according to el- Ceziri, it was brought to Aden from Ethiophia by a person namely, el- Zabhani, who unwillingly resided in African coasts for some time and then it was spread in Sufi world. Another rumour is that the person who brought coffee to Yemen is Seyh Ali b. Omer es-Sazili.

It is a common belief that this tasty drink was used in order to stay energetic and alert for long hours during praying and mentioning by the dervishes from the beginning of the XV th Century (Ayvazoglu, 2011). Popularity of coffee in Sufi world is the main factor to spread to wide areas by dervishes while travelling. Coffee was carried to İstanbul, Turkey by the vessels during the age of Suleiman the Magnificient (Birsel, 2003). First it had been roasting until it became black like a coal and had been drinking by passing it from hand to hand in taverns but it was forbidden for a while and after some time the ban was removed due to growing demand by the public. The attention of literary identities, political and religious authorities to the coffee and its prohibition had made it the particular 
Gedik, E., Erdonmez, S.,S. \& Atılgan, N., S. (2016). Influence of Turkish coffee culture on the design of small home appliances: Turkish coffee makers,

focus of Ottoman intellectual because of its pleasure -giving feature. As it is an acceptable drink in terms of moral values coffee took its place in Ottoman Life as a alcohol free and non-narcotic drink and it caused to create its own culture and tradition for years and to establish the opinion of coffee houses in minds with their architectural features and create a public opinion for promotion of coffee (Gursoy, 2012).

Demand for the coffee has been increased which spread all over the world within two centuries and became an indispensable drink in every country and there had been scarcity in the production due to lack of capacity in the production in Yemen to meet this demand and new studies have been introduced to grow coffee plant in other countries (Ayvazoglu, 2011). Despite the troubles in the coffee history, Turkish coffee has become an indispensable part of our lives with its own culture and tradition.

\section{Turkish Coffee Culture and Its Products}

Coffee which has a long history and quickly gained popularity not merely as a drink but also as a sociological phenomenon which shapes social relations and that is considered as a symbol of a status and has some rituals from its preparation to the consumption. Despite the fact that we sip this drink just as an "a cup of pleasure", it has become an instrument for "just an excuse to talk with others" other than a just a cup of coffee with its serving, drinking, even with its prohibition and traditions brought to present (Kaplan, 2011).

Today, Turkish coffee which has played an important role in our cuisine culture and became an instrument for pleasure after meals, an excuse for intimate talks, like a friend in sleepless nights and highly popular for ceremonies. It became the subject of Turkish proverbs, poems and folk songs: "a cup of coffee commits one forty years of friendship", "One neither desires coffee nor a coffeehouse. One desire to talk with others, coffee is but an excuse"...

In Anatolia, when a young man's family calls to ask a girl's parents for her hand in marriage, a formal coffee is served in the households. Prospective husbands would judge a woman's merits based on the taste of her coffee (Kaplan, 2011). One of the most important discoveries related to the coffee in Turkish language is the word "kahvaltı". Kahve+ altı means 'breakfast' which combines the words "coffee" and "before coffee" (Naskali, 2014) Almost all words , such as coffee, grind, (cezve) pot, telve (ground) and fincan (cup), that represent and reflect the coffee culture are stunningly beautiful.

Coffee is boiled by Arabs while preparing but it is roasted and ground in Turkish taste; and it is mentioned as the first making coffee in today's sense in the world (Naskali, 2014). The best recipe for making a Turkish coffee is as follows: It is prepared by cold spring water. (It is used a stone heat source for approximately 3 minutes to brew)First water, Turkish coffee, sugar and aromatic additives (if any) are added into pot. It is thoroughly stirred till a homogenous texture is obtained (do not stir for second time) before putting it on stove. It is brewed twice to get thicker foam. (Between 80-95 C temperature) When the foam gets thicker in texture take some of the foam into the cups. Take the pot off the fire and pour the rest into the cups (Turk Kahvesi Kulturu ve Arastırmaları Dernegi, 2008).

Cooking foamy Turkish coffee, which is called by French People as "Sultan's Coffee" is fine work that requires ability. A copper pot should be usually preferred for this and the size of the pot should be chosen according to the number of the persons (Ayvazoglu, 2011). Coffee should be cooked on the stove for 15- 20 minutes and the pot should be taken off the fire and put back again from time to time. Whatever the recipe is, a Turkish coffee without foam cannot be imagined any way (Gursoy, 2012). In the past, the coffee was used to cook on barbecue in the households. It is a common belief that the ash coffee which is cooked in the pot on fire at medium heat on the ashes of barbecue smells very nice and more tasty and with rich foam. 


\section{$D$}

The need for the utensils for roasting, cooling of the roasted beans, grinding, and preservation, cooking and serving for coffee beans paved the way for the development of practical, aesthetic products appealing to different tastes. In the early times metallic frying pans were used to roast the coffee (Fig.1. (a)). Like ladles, these pans had long handles that make their movements easy on the fire. Regular movements were needed in order not to produce excessive roast flavour and bitterness.

a

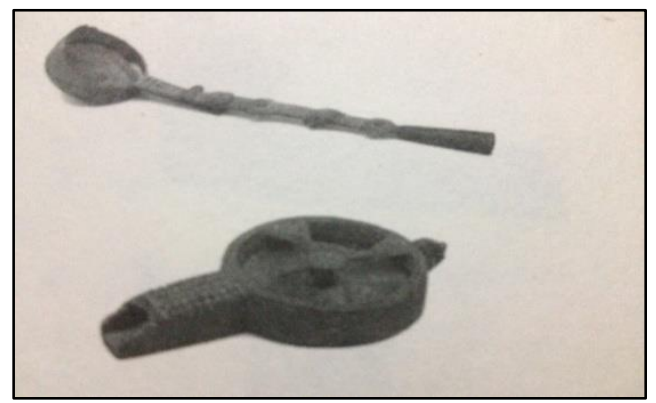

b

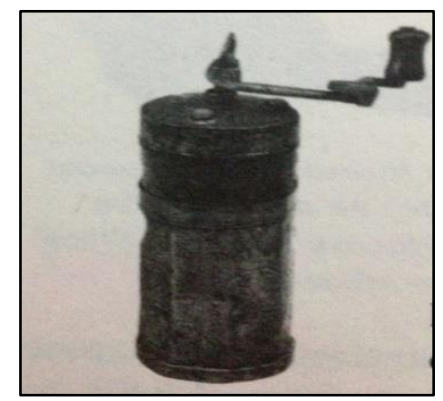

Figure 1. (a) Coffee pan with foldable handle (Ayvazoglu, 2011); (b) Coffee Grinder (Ayvazoglu, 2011)

While wooden mortars were used for grinding first, later on, coffee grinders were started to use (Fig. 1. (b)). Wooden coffee boxes were used to keep the freshness of ground coffee (Fig. 2. (a)). Tightly closable coffee boxes were of great importance not to let the air in.

a

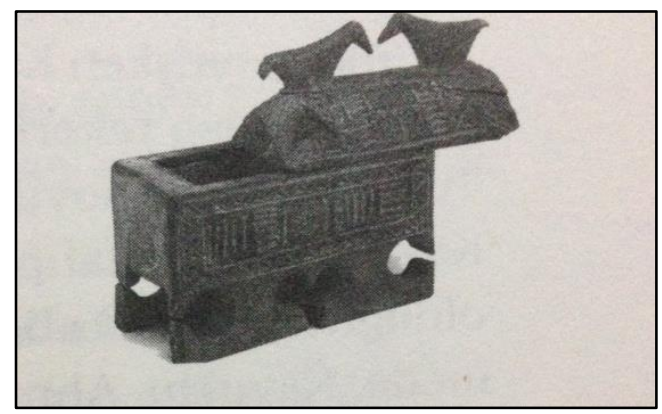

b

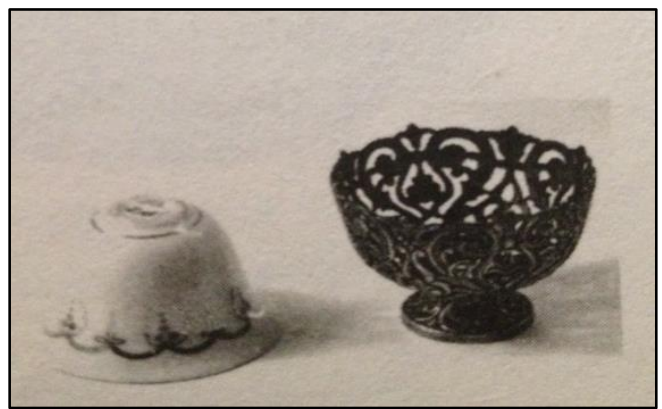

Figure 2. (a) Wooden coffee box (Ayvazoglu, 2011);(b) A porcelain cup without handle(Ayvazoglu, 2011).

Coffee used to drink in large bowls and soup basins then bowl size decreased in size. Pre heated porcelain cups were mostly preferred to keep the coffee warm and not to go cold (Soyturk, 2005). 
Figure 3. (a) Brazier set (Sitil)(Ayvazoglu, 2011); (b). Copper Pot (Ayvazoglu, 2011)

Brazier set was one of the utensils used in coffee serving ceremonies. Brazier set is composed of an ibrik and basin made from copper carried by chains on three points, tombac or silver (Fig. 3. (a)). We see cezve as an instrument used in making coffee in Ottomans besides Sitil (Fig.3. (b)). Cezve was a traditional design according to the tradition of cooking coffee on barbecue (Naskali, 2014). Cezve has a narrow mouth at the top with a large bottom. Turkish coffee needs to stay on fire for a while. Thus narrow surface contacts with air and this prolongs the boiling time. An object with a large surface will cause the liquid to boil very quickly. Furthermore, the foam of coffee boiling in a pot with cylindrical shape may distribute quickly due to large surface at the top. In the narrow neck, thick foam can be seen (Sunal, 2009). Long handle of cezve ensures to stay away from fire, protect from heat and easy control. On the left side of the handle there is a 'spout' which makes pouring coffee easy. Some bought cezves for elegantly design ornate with fine hand carvings. Sof 93( )-121vonm-5(f 93( (y)-3(an)5(t)9)8( )u)6( 

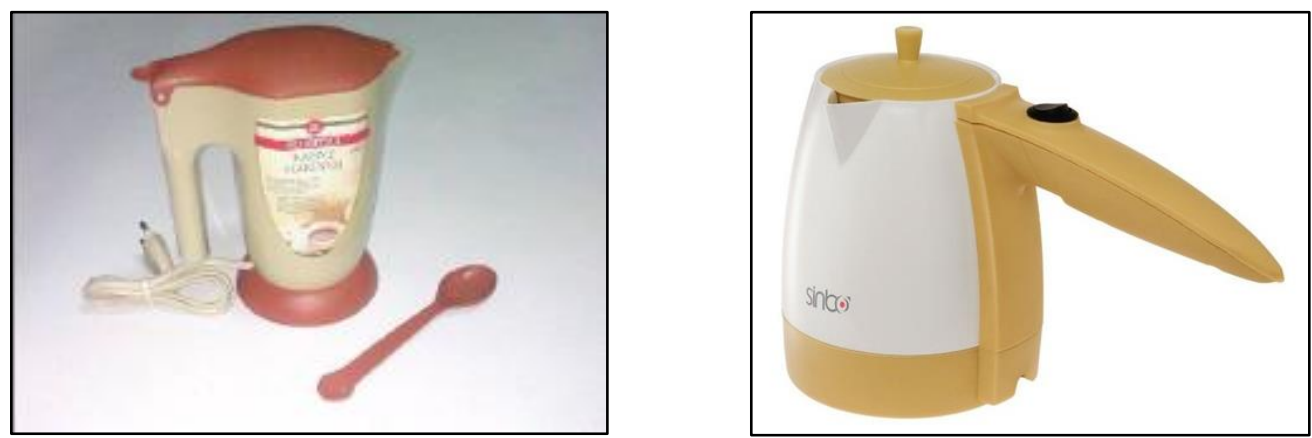

Figure 4. (a) Plastic Kettle- Coffee Machine (Kaygan, 2012); Plastic Electrical Cezve ( www.sinbo.com.tr)

Arzum "Kahwe" is an electrical cezve with plastic body and a foldable handle (Fig.5. (a)). Its distinctive features apart from other plastic cezves are its foldable handle like some usual cezves and automatic shut off features when brew is completed. This minimizes user control. It is without a large bottom and a narrow neck. Electrical cezves with metallic body are replaced by plastic electrical cezves in the market. Arzum "cezve" (Fig.5. (b)) and "mırra" (Fig.5.(c)) are electrical cezves with metallic body. Mırra is All Arab geography- specific, name of the bitter coffee which was brewed for several times. In both products traditional cezve shapes are preserved, however Mırra is more modern in style whereas "Cezve" is in traditional style.

a

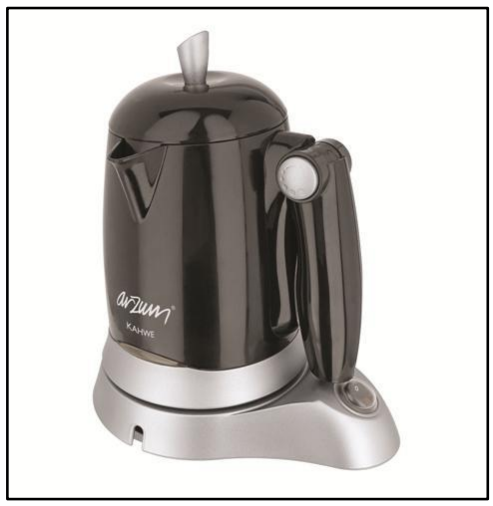

b

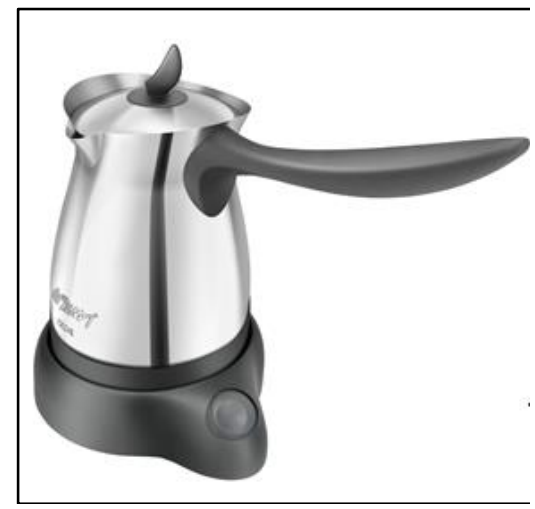

c

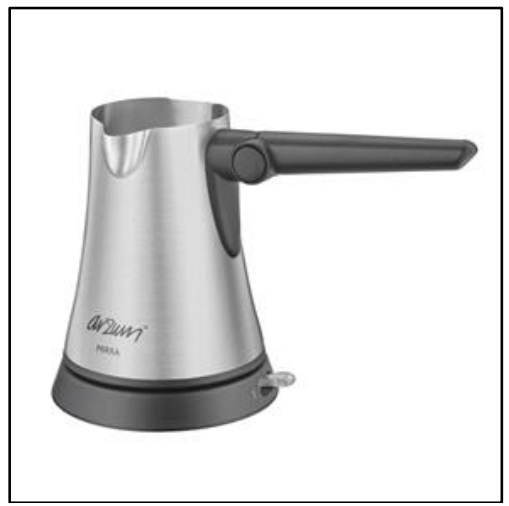

Figure 5. (a) Arzum "Kahwe" electrical cezve; (b) Arzum "Cezve" electrical cezve (c) Arzum "Mırra" electrical cezve (www.arzum.com.tr)

Starting point of electrical cezve with metallic body designed for coffee world is ash coffee as a traditional brewing method. Entire surface of electrical platform at the top is illuminated in order to give the resemblance of brewing coffee on a glowing fire (Fig.6. (a)). The product itself has an alternative with copper body as a reference to traditional copper cezves (Fig.6.(b)). 


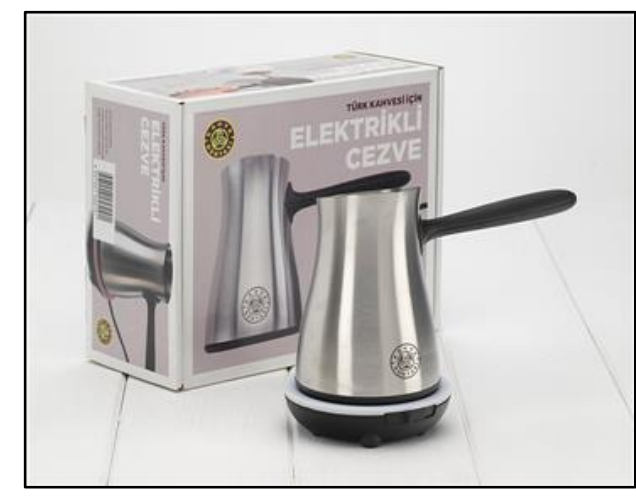

Figure 6. (a) "Kahve Dunyası" electrical cezve; (b) "r

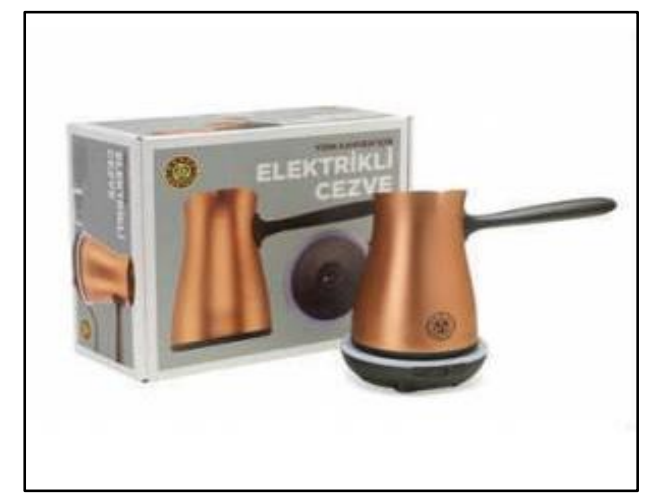

"Kahve Dunyası" copper electrical cezve (www.kahvedunyasi.com)

First full- automatic coffee machine placed on the market is Arçelik "Telve" (Fig.7. (a)). Telve means " residue at the bottom of the cup of Turkish coffee" (Naskali, 2014). Telve is a complicated machine which facilitates preparation of coffee in traditional taste without watching this process, gain proper texture and stirring thanks to its automatic water flow, prevent spillage and audio alarm system. It can serve up to 4 persons with its two separate reservoirs. Reservoirs resemble the form of cezve although its general appearance is different from traditional form. Long handle is not observed as there is no need to be protected against heat. After Telve, full- automatic Turkish coffee machine, Arzum "Okka" was placed on the market (Fig.7. (b)). The word "Okka" means smooth, proper and complete (TDK, 2014). In the Turkish coffe history the term "okkalı kahve" means coffee that is made with plenty of coffee grains and put into a large cup. Arzum "Okka" comes to the forefront with its automatic water intake and directly serving to the cup. In this machine is designed to give the same taste as traditional Turkish coffee making with its brewing at medium heat. The colours of copper and embroidery, the most important elements of the Turkish coffee culture were used in design. Traditional form of Cezve is not observed in the product.

a

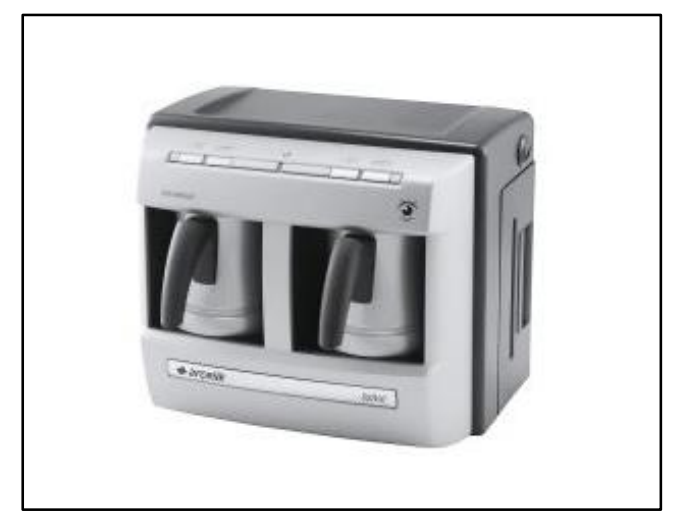

$\mathrm{b}$

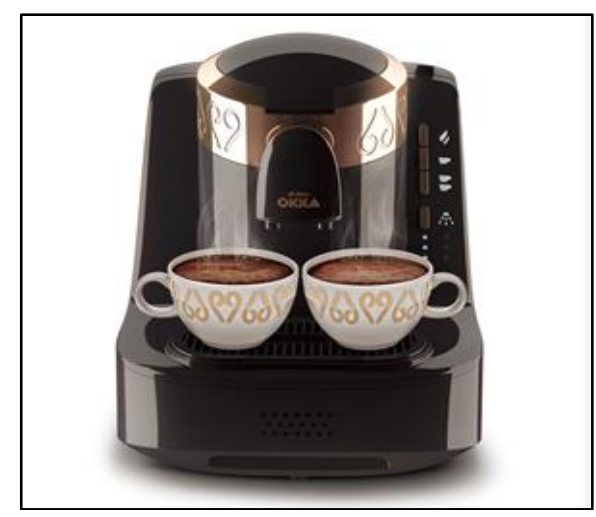

Figure 7. (a) Arçelik "Telve” Full Automatic Turkish Coffee Machine (www.arcelik.com.tr) ; (b) Arzum “Okka” Full Automatic Turkish Coffee Machine (www.arzum.com.tr)

\section{Conclusion}


Turkish coffee which has been a part of our lives for 500 years became our national drink. Its preparation, brewing, servicing and the use of its utensils are the elements of a traditional ceremony. However, it has kept up with today's modern life and undergone certain changes. The most concrete evidence for that is today's Turkish coffee machines. In this study, the traces of Turkish coffee culture captured in Turkish coffee machines are as follows:

- Certain names were used belonging to Turkish coffee culture (mırra, okka, telve, cezve etc.)

- Traditional form of cezve has been preserved. Bottom side is large to obtain maximum yield and the neck is narrower to get thick foam.

- Despite the fact that there is no reason to place handle to be protected against heat, the handle is longer in order to control the use of cezve like in the traditional form.

- Foldable handle and the cap exist as observed in traditional cezves.

- Copper motifs and hand carvings belonging to traditional Turkish coffee culture have been used.

- Visual elements attributed to coffee brewing on ember were used.

- "Slow cooking button "is a concrete reflection of traditional Turkish coffee culture. Traditional Turkish coffee is brewed at medium heat.

- A system is employed to prevent overflow in order to get a thick foam which is most important feature of Turkish coffee

These results show that Turkish coffee culture has concrete reflections on designs of Turkish coffee machines in functional, aesthetical and logical sense. It can be said that this is a factor explaining the reason why coffee addicts accept and prefer these products.

\section{References}

Ayvazoglu, B. (2011).

Balaman, A. R. (1981). Geleneksel yasamda kültürlenme (toplumsallasma) süreci . $\quad T$ $H$

Basarır, S, (2005).

$T$

$D$

$\begin{array}{ll}T & T\end{array}$

Birsel, S. (2003).

Gursoy, D. (2005 T

Guvenç, B. (1979).

. Yuksek Lisans Tezi, İzmir Yuksek Teknoloji Enstitusu, Izmir. , Istanbul: Koza.

. Istanbul: Remzi.

Istanbul: Oglak.

Hattox, R., S. (1998). . Istanbul: Tarih Vakfi Yurt.

Kaplan, M. (2011). Bir Fincan Keyif: Kahvenin Oykusu. Yurt ve Dunya Dergisi /

Kaygan, H, (2012). 11-13. Retriewed from: http://www.yurtvedunya.net/full/url/

Doktora Tezi, The University of Brighton, UK. . Istanbul: Kitabevi.

Naskali, E. (Ed.) (2014).

Onal, G. (2011). Yaratıcılık ve Kulturel Baglamda Mimari Tasarım Sureci. H

Soyturk, M. (2005). $M$ . Istanbul: Filiz.

TDK (2014). Guncel turkçe sozluk. Ankara.

TKKAD. (2008). $T$ Arastırmaları Dernegi, On-line sheets. 1-27.

. Turk Kahvesi Kulturu ve 